\title{
The Political Dynamics on Development Process of Human Rights Cities: Lessons from South Korea and Indonesia
}

\section{Zico Mulia}

\begin{abstract}
There has not been a comparative study on the human rights cities in South Korea and Indonesia. Therefore, this paper conduct a comparative study of the dynamics within the development process of the human rights city in Gwangju and Wonosobo. This study explains how both cities flourished into Human Rights Cities using agenda-building theory. Moreover, this research elucidates the main actors and their respective roles in the development of both Human Rights Cities. Employing qualitative methods of data collection and analysis, this study found similarities and differences between the development processes of both Human Rights Cities. This article found that civil society organizations' efforts were influential in the initiation stage in Gwangju. Meanwhile, in the case of Wonosobo, the concept of brandishing itself as a Human Rights City came from the Mayor. As a result, the top-down agenda-building process in Wonosobo took place faster than the development of the bottom-up human rights city of Gwangju.
\end{abstract}

\section{Keywords}

Human rights; city; agenda-building; Gwangju; Wonosobo

\section{Introduction}

For almost two decades, the concept of Human Rights Cities has spread and become a global phenomenon in a variety of locales of which include several Asian countries. The human rights city is a global initiative with the aim of encouraging the embodiment of human rights at a local level. It is based on the recognition of cities as key players in the protection of human rights and, as a concept, generally refers to a city whose local government and local population are morally and legally governed by human rights principles (Human Rights Council 2014, 11). The initiative of human right cities serves as a departure from the idea that all city residents must understand human rights in order for international human rights norms and standards to be effective as a framework for sustainable development (Marks, Modrowski, and Lichem 2008, 46).

Zico Mulia is a program officer at Tifa Foundation. He completed his Master's degree in NGO Studies in Department of Non-Governmental Organization Graduate School Chonnam National University, South Korea.

\section{Corresponding Author:}

Zico Mulia, Yayasan Tifa, Jakarta, Indonesia.

Email: zico.mulia@gmail.com 
In Asia, Gwangju plays an important role in mainstreaming the concept of the Human Rights City at both regional and global scopes. In recent years, this metropolitan city has been known as bustling city for human rights and democracy discourse, as evidenced by a significant number of organizations catering to these causes. The City became a symbol of the human rights city when the Asian Human Rights Charter in collaboration with the Asian Human Rights Commission was announced for the first time in Gwangju amongst the presence of other Asian cities in 1998 (OHCHR 2014). In other Asian countries, such as Indonesia, the human rights cities have only emerged less than a decade ago. One of the human rights cities in Indonesia is Wonosobo Regency (city level), in the province of Central Java. Wonosobo is considered as one of the most tolerant and safest cities for ethnic and religious minority groups in recent years.

This study conduct a comparative study of the dynamics within the development process of the human rights city in Gwangju and Wonosobo. The author wants to compare both human rights cities through the framework of agenda-setting. The research question in this study is: How two cities established the human rights city? The reason I chose this research topic is because there has not been a comparative study on the human rights cities in South Korea and Indonesia focusing on the dynamics of the development process.

\section{Literature Review}

\section{Building Human Rights Cities}

In 1997, the city of Rosario became the first to declare themselves as a Human Rights City after several local NGOs and the city's mayor jointly signed a proclamation expressing their commitment to building a human rights community as well as promoting respect for human rights, equity, and peace. This concept was further developed, especially as a normative concept, by the World Human Rights Cities Forum, an annual conference for global human rights cities to convene and discuss best practices which take place in the city of Gwangju (Republic of Korea).

Three decades prior to Rosario's declaration as a human rights city, a rightsbased discourse on urban policies first surfaced in the 1960s as part of a much wider scene of social protests against capitalism and the vested authorities of the decade. One influential work that affects the notion of a Human Rights City comes from Henry Lefebvre's "Right to Urban Life". Lefebvre found that the notion of the right essentially constituted a collective right. Accordingly, he envisaged a "radical restructuring of social, political, and economic relations, both in the scope of the city and beyond". This notion would influence right to the city movements across Europe as well as North and Latin-America. Lefebvre's "right to the city" has also become the locus classicus in an ever-growing body of scholarship on "rebel cities" and "just cities" that conceptualizes the city as essentially the equivalent of a social organization (Oomen 2016).

Regarding the initiator in the construction of the human rights city, two studies (Oomen and Baumgartel 2014; Van den Berg 2016) as concluded by Barbara Oomen (2016) contended that most human rights cities start as an 
initiative taken by an enthusiastic individual or NGO with an interest in the theme. For example, the Mayor of Utrecht has the initiative to build a human rights a city after giving a speech about human rights a cities at an international conference; university teachers who played key roles to change the city of Graz in Austria into becoming the first human rights city in Europe and having Montreal adopt the right to the city; and the San Francisco councilor who managed to enact human rights obligations at the local level. In order to achieve success to give human rights meaning at the local level, individual enthusiasm needs to expand towards the formation of a broader coalition of both governmental and non-governmental parties (Oomen 2016, 8).

In his paper, Van den Berg (2016) discussed about 'horizontal' alliances of actors. He elaborates on the role of civil society in the rise of human rights cities. In the Netherlands, civil society has functions as an initiator of raising the urban relevance of rights, as a key partner in strategic alliances, and as an intermediate space contributing to rights consciousness. Frate (2016) discussed the role of global networks in the initial process of making Charter and the specific role of the Ombudsman in its implementation. The charter is naturally glocal which was inspired by the international human rights law in general and by the European Charter for Safeguarding Human Rights in the City more specifically. In his study explained about the deliberation process that involved various groups of actors including a vibrant civil society starting from designed stage, drafted to enacted in 2006.

Discussing the implementation of global urban justice in York (United Kingdom), Graham, Gready, Hoddy and Pennington (2016) elucidate the importance of enthusiastic individuals or initiators to expand to the formation of broader coalitions that include both governmental and non-governmental parties. The York Human Rights City project included the Council of York City, the international Service and the Joseph Rowntree Charitable Trust, and also other local social justice organizations and the university. The cities manifest a new form of human rights practice, not in a singular, top-down way, state-focused strategies to multi-dimensional, but involving multiactors, contextual and bottom-up approaches. An important experience of the York Human Rights City Network is that local stakeholders unite not only to mobilize human rights at the local level, but also form responses to human rights issues at the national level.

Other research on actors and their shifting responsibilities, Kamuf Ward (2016) discusses the role of mayors in bringing human rights to the cities in US -with specific Race Convention (International Convention on the Elimination of All Forms of Racial Discrimination). Because the federal government only ratified three of the core human rights treaties and has put significant limits on its application domestically. This study highlights why the mayor is a valuable partner in practicing anti-discrimination policies in his jurisdiction by offering a framework for the mayor's authority and responsibility to implement human rights. Its also explores the (regional) Coalition's Plan as a concrete entry point for US mayors to utilize human rights principles to address discrimination. 
Other study by Marta F Davis $(2017,66)$ looks at cities' structural governance relationships and the impacts of those arrangements in the US context, building alliances with international human rights organizations is also an important element in building the human rights city. The last one, in a study that focuses on three human rights cities in Indonesia (Palu, Wonosobo and Bojonegoro) by Nurkhoiron (2017), it was also found that the success of pushing the Human Rights Cities, both in Palu, Wonosobo and other cities cannot be separated from the role of CSOs. This literature study addresses the interaction between NGOs and the mayors to formulate the concept of a human rights city and discusses the main issues in each region that underlie local policy making as its legal framework. However, it is not easy to create networks with CSOs in an effort to escort the human rights city.

The above studies have their own contribution and focus on: initiating actors, structural governance relationships, the role of civil society and global networks and the implementation of human rights cities. But the study of cities in Europe, America, Canada, and Asia does not fully explain the dynamics of the development of the Human Rights City from the initiation stage to the entrance or into local policy. Therefore, this study was conducted to explain the dynamics of the development process of the City of Human Rights in Gwangju and Wonosobo from the initiation stage to the issuance of formal legal and local policy practices.

\section{Agenda-Building as Analytical Framework}

This study uses the theory of agenda-building as a analytical framework. Cobb and Elder (1983) examine the processes of participation, mobilization, and media participation in the American polity. They assayed the problems of agendabuilding and issue access in the context of four analytic frameworks namely: systems theory, power analysis, decision-making schema, and the group approach. They describes the term agenda as "a general set of political controversies that will be viewed at any point in time as falling within the range of legitimate concerns meriting the attention of the polity. ..It may also be used to denote a set of a concrete, specific items scheduled for active and serious consideration by a particular institutional decision-making body" (Cobb and Elder 1983, 14). According to them, the agenda is divided into two based on scope and domain: systemic agenda and institutional agenda. The first type is more abstract, general and broader than the second.

As for what is meant by issue is defined as a conflict between two or more identifiable groups over procedural or substantive matters relating to the distribution of positions or resources (Cobb and Elder 1983, 82). There are four means by which issues are created. First, the most common method is the creation of issues by one or more contending parties who perceive an unfavorable bias in the distribution of positions or resources. Such initiators are labeled "readjustors". The second form of issue creation is by the person or group who manufacture an issue for their own gain. Such individual may be labeled "exploiters." Another means of issue initiation is through an unanticipated event. Such events called "circumstantial reactors." The latter are issues that generated by the persons or 
groups who have no positions or resources to gain for themselves. They might be called "do-gooders" because they oftenly acquire psychological feelings to do what they believe in the public interest.

In general, Cobb and Elder's work provides a comprehensive explanation of agenda-building dynamics. But their work only focuses on the political context of America which has a federal republican government system. This system is different from the system of government in Korea and Indonesia, which are republics with a unitary state. The development of democracy between America and the two Asian countries is also very different. As mentioned in the literature above, Korea and Indonesia have experienced decades of authoritarian rule under the military regime for decades.

In the Agenda Building as a Comparative Political Process, Roger Cobb, JennieKeith Ross and Marc Howard Ross $(1976,126)$ explained about agenda building which is as a process by which the demands of various groups in the population are translated into items vying for the serious attention of public officials.There are three models describes different ways in which the public can influence the structure of political agendas are: outside initiative, mobilization and inside access. The first model, the outside initiative model, accounts for the process through which issues arise in non-governmental groups and are then expanded sufficiently in reaching public agenda and then, the formal agenda. The second model, the mobilization model, considers issues which are initiated inside government and consequently achieve formal agenda status almost automatically. The third model, the inside initiative model, describes issues which arise within the governmental sphere and whose supporters do not try to expand them to the mass public.

There are three different models of agenda-building depending on variation in the four major characteristics of issue careers: initiation, specification, expansion, and entrance (Cobb, Ross, and Ross 1976, 126). To illuminate clearly the dynamics of the development of Gwangju Human Rights City and Wonosobo Human Rights City, the author will use agenda-building theory based on the three models and the four stages. I would like to explain briefly the definition of the four stages above for the three models in the table below.

Table 1. The three models and the four stages in the agenda-building

\begin{tabular}{|l|l|l|l|l|}
\hline $\begin{array}{l}\text { Three } \\
\text { Models/Four } \\
\text { stages }\end{array}$ & Initiation & Specification & Expansion & Entrance \\
\hline $\begin{array}{l}\text { Outside } \\
\text { initiative }\end{array}$ & $\begin{array}{l}\text { Articulation of } \\
\text { general issue }\end{array}$ & $\begin{array}{l}\text { From general } \\
\text { issue to } \\
\text { specific } \\
\text { demands }\end{array}$ & $\begin{array}{l}\text { Getting on } \\
\text { the formal } \\
\text { agenda by } \\
\text { create } \\
\text { pressure to } \\
\text { the decision } \\
\text { makers }\end{array}$ & $\begin{array}{l}\text { Movement from } \\
\text { public agenda to } \\
\text { formal agenda, } \\
\text { serious } \\
\text { consideration by } \\
\text { decision makers }\end{array}$ \\
& & & \\
\hline
\end{tabular}




\begin{tabular}{|l|l|l|l|l|}
\hline Mobilization & $\begin{array}{l}\text { Program/policy } \\
\text { announced by } \\
\text { decision makers } \\
\text { want to be a public } \\
\text { agenda }\end{array}$ & $\begin{array}{l}\text { What is } \\
\text { expected of } \\
\text { the public in } \\
\text { terms of } \\
\text { cooperation } \\
\text { or support }\end{array}$ & $\begin{array}{l}\text { Try to } \\
\text { expand the } \\
\text { issue to new } \\
\text { groups in the } \\
\text { population }\end{array}$ & $\begin{array}{l}\text { Moving from the } \\
\text { formal to public } \\
\text { agenda, as } \\
\text { significant portion } \\
\text { of the public come } \\
\text { to recognize the } \\
\text { program }\end{array}$ \\
\hline $\begin{array}{l}\text { Inside } \\
\text { initiative }\end{array}$ & $\begin{array}{l}\text { Agency or a group } \\
\text { within the } \\
\text { government, or a } \\
\text { group with close } \\
\text { ties to } \\
\text { governmental } \\
\text { leaders, may } \\
\text { articulate a } \\
\text { grievance or a new } \\
\text { policy proposal }\end{array}$ & $\begin{array}{l}\text { Originating } \\
\text { groups or } \\
\text { agency make } \\
\text { a series of } \\
\text { concrete } \\
\text { proposals } \\
\text { addressed to } \\
\text { other } \\
\text { government } \\
\text { leaders and } \\
\text { decision- } \\
\text { makers. }\end{array}$ & $\begin{array}{l}\text { The policy } \\
\text { initiators } \\
\text { might seek } \\
\text { to involve an } \\
\text { identification } \\
\text { group and } \\
\text { selected } \\
\text { attention } \\
\text { groups, in } \\
\text { order to give } \\
\text { their issue a } \\
\text { higher } \\
\text { priority }\end{array}$ & $\begin{array}{l}\text { Entrance means } \\
\text { attaining formal } \\
\text { agenda status. But } \\
\text { it does not mean } \\
\text { that the issue on } \\
\text { the public agenda }\end{array}$ \\
\hline
\end{tabular}

\section{Characteristics of Gwangju City and Wonosobo Regency}

Gwangju city which located in the southwest corner of South Korea is the leading city of the Honam region, with the entire nation within a day's reach. The city has long been regarded as a city rich in culture and arts. After government of South Korea was established in 1948, Gwangju-bu was changed into Gwangju City in 1949. In early 1995, Gwangju's status changed to Metropolitan City (neargov, n. d.). Gwangju played a central role in facilitating interchanges between those living in the mountainous area and others in the plains region. The city has a population of 1.482.151 people and Local Tax Revenues of 4.687 million won. In 2018, Gwangju had a birth rate of 28 and a death rate of 21 . The population movement rate is 1.163 (Gwangju 2018).

Gwangju Metropolitan City known as A Sacred Land of Democratization and a City of Democracy, Human Rights and Peace. Gwangju has a long history of people movements and democracy like movement since the end of the Joseon Dynasty to the Gwangju Student Independence Movement and the May 18 Democratization Uprising in 1980. The latter event is an important event that has a significant impact on democratization and demilitarization policies in the Republic of Korea.

Unlike Gwangju, the status of the Wonosobo government in the Republic of Indonesia is Regency. After Indonesia's independence, Wonosobo was established as Wonosobo Regency in 1950 along with 27 other districts based on Law no. 13 of 1950. These laws revoked the provisions of the 1929 Dutch Colonial Government (Staatsblad) law concerning the establishment of district autonomous areas within the Central Java Province. Regency and cities have equal levels and have their own 
local governments and legislative bodies. In general the regency is wider than the city. The Regency is headed by the Regent, while the City is led by the Mayor. Both are selected through a general election process (BPS 2018).

Wonosobo Regency located in the mountain in Central Java province in Indonesia. Because geographically located in the mountains, the potential of this Regency is agriculture and plantations. Its commodities include potatoes, sweet potatoes, carica and coffee. At the end of 2018, the total income of Wonosobo Regency is 1.8 trillion Rupiah or 131 million US Dollar. The area with population 784,091 (2017) is administratively divided into 15 sub-regencies (wonosobokab.go.id). Population density of Wonosobo Regency in 2017 reached $796 / \mathrm{km} 2$.

\section{Methods}

Qualitative methods of data collection, such as primary sources through interviews and documents analysis, have been used in this study. To examine these two cities from two different countries, Gwangju in Republic of Korea and Wonosobo in Republic of Indonesia, the researcher used comparative case study analysis. Semi-structured key informant interviews with representatives of municipalities, civil society organizations (local, national, and regional/international), and experts from both cities. For each interview, I will keep the interviews open-ended and not rigidly follow a specific line of questioning during the interviews. Secondary data analysis was carried out through in-depth analysis of articles, books, documents, newspapers, and other related sources. The literature comes from NGOs, academics, city governments, and mass media.

\section{Results and Discussion}

\section{Political Economy Circumstances in Gwangju and Wonosobo}

After a decade after the starting point for the transition to democracy in June 1987, the Republic of Korea has adopted local government ordinances concerning on human rights. Start with the initiative taken by Gwangju City in 2009 which enacted the "Promotion of Human Rights, Democracy and Peace City" ordinance (Gwangju City 2018, 5). This policy provided a legal foundation for developing and implementing human rights-friendly policies. In addition, the Seoul Municipality enacted human rights ordinance in 2012 to govern the establishment of local human rights committees to review local government human rights action plans and provide advice on local human rights issues (Human Rights Council 2019, 3). The main challenges faced by local government in the protection and promotion of human rights are political, economic and administrative (Human Rights Council $2015,9)$.

The Gwangju City Government, which is part of the South Korean unitary state with limited decentralization, is granted autonomy in several aspects. In unitary states, the central government generally bears responsibility for planning, programming, regulating and funding housing, and local governments manage 
implementation with varying degrees of autonomy (Human Rights Council 2015, 4). The level of democracy and public participation that were the main pillars in the practice of decentralization and regional autonomy were very low in the era of authoritarian-military rule from the 1960 s to the 1980s. Before Gwangju was known as a city of human rights and democracy in the late 20th century, it had long history of the struggle of its people against tyranny to uphold democracy. This history has an impact on the political situation in the Republic of Korea.

In the era of the independence of the Republic of Korea, there were two important events for the history of the democratization movement, namely, the April 19th Revolution of 1960 that toppled the authoritarian regime under President Syngman Rhee and the First Republic to the May 18th Gwangju Democratization Movement that fought against oppressive government under General Chun Do Hwan. During the 1970s and 1980s, the military regime (under the leadership of President Park Chung Hee who was assassinated in 1979 and was later taken over by General Chun Do Hwan) forced most citizens into compliant subjects in various ways such as imposing a curfews, torturing political activists, searching for citizen's belongings on the street, silencing the voices of the left in the public arena, and so on. During this repressive period, Koreans citizens were avid to have more political rights such as freedom of speech, expression and assembly, but this was repeatedly denied by the military government (Lee 2007).

In 1980, the people's struggle of the May 18th Gwangju Democratization Movement led to thousands of victims and considered the 'avant-garde' of the modern democratization movement in South Korea. Its spirit has inspired the Asians and also people around the world as an important asset that emphasized the values of human rights (OHCHR 2014, 1). The important democratization event that occurred after May 1980 was the June Democracy Movement in 1987. At that time there were mass demonstrations against the dictatorship and the enforcement of democracy which led to direct presidential election system (Gwangju City 2018).

Efforts to preserve the values of the struggle for democratization in May 1980 and June 1987 were institutionalized by the central government and Gwangju municipality in various forms. In the early 1990s, there was hard efforts by civil society and broad support from all ranks of people (including professors, teachers, writers, religious leaders, farmers, women, and political representatives) to reevaluate history and come to terms with the past finally succeeded when President Kim decided to write the Gwangju Special Act into law (Jong-cheol 2002). Among them through the establishment of memorialization, education and annual commemoration in public spaces. These events solidifying its position as a city of democracy, human rights and peace.

The political change from authoritarian rule under military control to civilian government in the early 1990s had the effect of increasing civil society participation in various aspects including human rights. As stated by Na Kahn-chae, this change cannot be separated from the people's struggle in the May 18 Movement because this movement led the struggle to a victory to end the military autocracy, and now embodies the movement for democratization and human 
rights (Kahn-chae 2001, 490). The functioning of the Transitional Justice mechanism such as the court against the main actors of the violence perpetrators in the May 18 Democratic Uprising events such as Chun Do Hwan and truth disclosure have had a positive impact on the enforcement of human rights and democratization in South Korea.

In 1998 the Gwangju Citizens' Solidarity declared the Asian Human Rights Charter in collaboration with the Asia Human Rights Commission. It is believed that people who are members of the May 18 Foundation individually and institutionally are involved in these monumental events.

Similar to South Korea, Indonesia is a unitary state that began to try to implement decentralization better after the transition to democracy in the late 1990s. In the era of authoritarianism of the Soeharto regime, Republic of Indonesia in practice carried out centralistic governance for more than 3 decades. Suharto became the second President of Indonesia to replace Sukarno from 1967 to 1998 due to national political turmoil and the cold war. During the Suharto New Order era, civil society participation was low because at that time the state was authoritarian with an ideology that prioritized political stability for economic development. So that the characteristics of the relationship between the central and the regional government are more directed towards centralization (Prayudi $2014,301)$. The social and political situation in Wonosobo is influenced by local and national politics.

There was social and political conflict in Wonosobo since decades ago. Similar to the state violence that occurred in Gwangju in 1980, in Wonosobo there were also human rights violations such as the mass killings of people accused of being members of the Indonesian Communist Party in 1965-1966. This was revealed after a mass grave excavation in 2000 initiated by NGOs and victims' communities (hukumonline 2003). The process of demolition of mass graves with permission from the Regent of Wonosobo, Dewan Perwakilan Rakyat Daerah/ DPRD (local parliament), military, and police in Wonosobo at that time, found the framework of 24 people in overlapping positions who were allegedly killed between March 3 and 6, 1966.

Based on the results of the 2012 National Human Rights Commission investigation, the 1965-66 massacre was a systematic and widespread violation of human rights that occurred in Indonesia with forms of crime such as killing, rape, torture, slavery, and forced eviction or resettlement (kompas 2016). Until now there has been no attempt from the state to fulfill the rights of victims of gross human rights violations in 1965-1966. This issue is still a hot topic for broad discussion.

In Wonosobo there also exist conflict of interest among stakeholders involving farmers, forest officers, government officials, and several private companies in the region. Economic pressure has been identified as main factors of conflicts the main factors of conflict that have a negative impact on the ecological and socio-cultural sustainability of the plateau. The economic crisis that occurred in 1997-1998 gave rise to ecological conflicts involving Perhutani (state forest company) employees, farmers and capital owners to use forest land to become agricultural land 
(Setyawan 2012). During the transition of power to the reform era in the 19982000s there was forest looting and conflicts between people around the forest and Perhutani, a State-Owned Enterprise in Indonesia which has the task and authority to carry out planning, management, exploitation and protection of forests in the region it works, in Java Island include Wonosobo (Suprapto and Purwanto 2013, 6). The impacts of forest looting and changes in land use for commodities that provide economic benefits to the community such as potatoes and vegetables have an impact on environmental damage (Suprapto and Purwanto 2013, 26).

After the fall of the military regime under Suharto then entered the era of political reform in Indonesia after 1998, there was a change in the national political landscape and also local politics. The 1998 reforms had consequences for the fragmentation of power between the states at the central level and the states at the local level becomes more apparent. This is related to the preferences of local interests that cannot be determined solely by the central government. Therefore reform also sees the need to reorganize power relations between the central and the regions.

The Law on Regional Government mentioned that the Regional Government which covers the Province and Regency/City has the authority for Obligatory Government Affairs and Optional Government Affairs. Obligatory Government Affairs are Government Affairs which must be held by all Regions. Obligatory government affairs include those relating to basic services such as education; health; public works and spatial planning; public housing and residential areas; and matters not related to basic services such as labor; women's empowerment and child protection; food; land; living environment; and population administration and civil registration (Law No. 23 of 2014). Most of the Obligatory Government Affairs contain points in the International Covenant on Economic, Social and Cultural (Ecosoc) Rights. The Indonesian government ratified the Ecosoc Covenant and adopted it into the national law in 2005.

Wonosobo Regency, under the leadership of Regent Kholiq Arif, has experienced an improvement in terms of economic and social conditions in the community. There have been four major changes until now. Despite this, sociocultural conflicts still occur because clash between religions and beliefs, local politics and economic problems still occur in the last few years. Even conflicts between villages often occur. Before being led by Regent Kholiq Arif for two periods (2005 - 2015), the social situation in the community was not safe. Crime and social conflict rates are quite high because of economic level is low. From 2013 BPS (Central Statistic Agency) data, the poverty rate in Wonosobo Regency is still 22.08 percent, which makes this Carica fruit-producing region the poorest Regency in Central Java Province (wonosobokab, n.d.).

Regent Kholiq also stated that previously the Regency of Wonosobo was notorious as the regency of conflict (Kholiq Arif pers. comm., June 7, 2019). During the second period (2010-2015), Wonosobo Regency under his auspices was known to reduce conflict, and increase security problems and protect minority groups (Tempo 2013). The effort he made was to approach various religious groups, communities and even thugs and collaborate with the army to maintain security 
and harmony in the region. From 2006 to 2015 the social and political situation of Wonosobo Regency improved considerably. This is evidenced by the many awards achieved by the Regency of Wonosobo (wonosobokab, n.d.).

\section{Processes of Establishing Human Rights City: From Initiation to Declaration}

The initiation process of Gwangju Human Rights City was closely related to civil society efforts in resolving past human rights violations, in this case May 18 Democratization Movement. The May 18 Memorial Foundation in 1994 became one of the important milestones in the process of building Gwangju as a Human Rights City. From 1994 to 1998, forums involving regional and international civil society networks were held such as the International Symposium on May 18 (1994, 1995); The 1st International Youth Camp for Human Rights and Peace (1996); Publication of testimony by foreign journalists covering the Gwangju massacre (1997) to the important moment for Asian civil society and the first time announced in Gwangju among Asian cities, Declaration of the Charter of Human Rights in Asia (1998). After the declaration of this Asian peoples charter, Gwangju symbolized as a city of human rights, continues with program and events involving international participation such as Gwangju Prize for Human Rights (2000) which hold annually by May 18 Foundation.

In 2003, the government established a Comprehensive Plan for the Development of a Democratic, Human Rights and Peace City, to promote the human rights of citizens (GJHR, n.d.). It was proposes to make the concept of human rights more concrete and realize it comprehensively in the city of Gwangju. This plan is an initial commitment of the Gwangju City government to its citizens to promote their human rights. After that, municipality ordinance to help the minority groups such as the migrants, foreigners, handicapped, Youth, and the Elderly enacted in 2005. At the same year, Gwangju Office of the National Human Rights Commission established as the hub of regional human rights administration (WHRCF 2011).

The Gwangju Metropolitan Council adopted the "Gwangju City Ordinance to Build a City of Democracy, Human Rights and Peace" in 2007 as the first local city council, which provided a legal foundation for developing and implementing human rights-friendly policies in the city. The Ordinance was established to promote the human rights city growth. Other ordinances enacted during the same time period were related to children, teenagers, disabled individuals, foreigners, multicultural families, and elderly (Gi-Goon 2012, 134). Local ordinance to support the development of Human Rights City began in 2009 with the enactment of the "Promotion of Human Rights, Democracy and Peace City" ordinance (Gwangju City, n.d., 5). This ordinance was a revision of the 2007 human rights city ordinance, which is considered insufficient in determining the practical methods of promoting human rights.

In 2010, the city actively launched the Human Rights City Project after the beginning of the 5 th term of democratically elected local government heads in Korea. The project focuses on establishing the comprehensive human rights promotion system designed to protect and improve human rights. Then in the 
same year in August the municipality established a department dedicated to Human Rights. The Human Rights Management Office was formed by appointing external human rights specialists (OHCHR, n.d., 4-7). This office handles the tasks to recall and inherit the 5-18 spirit that holds the philosophy and theory of the human rights city, and also manage to establish and promote human rights related issues. The table below made by Kim Gi-Gon in the 2012 World Human Rights Cities Forum report, shows various projects carried out by the Human Rights Management Office (Gi-Goon 2012, 139).

In 2011, the second revision of the Ordinance, involved the participation of public organizations, city councils, and experts through public hearings and meetings. The result was the establishment of Municipality Ordinance on Human Rights Guarantee and Promotion in January 2012 (Gi-Goon 2012, 135). The contents of this Ordinance consist of four chapters namely. : General Rules, Policies for the Assurance and Promotion of Human Rights, Policies for the Promo Democratic, Human Rights and Peace Cities and Citizens' Committee for the Promotion of Human Rights. It contains an improvement from the 2009 Ordinance regarding the responsibility of Gwangju City to build an organization and implementation system to guarantee the rights and the realization of such rights.

Gwangju Metropolitan City with the May 18 Memorial Foundation, organized the World Human Rights Cities Forum in May 2011. At the forum which was attended by more than 100 participants consisting of mayor, city representatives, UN experts and human rights NGOs from Asia and across the globe, produced the Gwangju Declaration on Human Rights City (UCLG 2011). The declaration defines the human rights city as a local community, as well as a series of sociopolitical processes in a local context, where human rights play a key role, as fundamental values and guiding principles. In this forum, the Gwangju Metropolitan City along with representatives of local governments, human rights organizations and experts from various countries declared their commitment to build the Human Rights City.

A human rights city requires human rights governance together in a local context. Where local governments, regional parliaments, civil society, the private sector, and other stakeholders work together to improve the quality of life for all, in the spirit of partnership, based on standards and human rights norms. It also emphasizes the importance of ensuring broad participation of all actors and stakeholders, especially marginalized and vulnerable groups, and the importance of effective and independent human rights protection, as well as monitoring mechanisms that involve all people. The final part of the declaration mentions five commitments to Human Rights City and recommend Gwangju Metropolitan City continue to organize the World Human Rights Cities Forum as a platform for the global promotion of the "human rights city" movement (UCLG 2011). The forum is still being held every year.

Based on the investigation of the development process of the Human Rights City in Gwangju from the initiation process to the declaration, the author found no evidence that anyone opposed this effort. Kim Hyun's answer, Chief of Human Rights \& Peace Cooperation Office, when author asked this question also confirmed that there were no parties who opposed Gwangju's development as a Human 
Rights City (pers. comm., June 14, 2019). According to Yoo Geunjong (pers. comm., July 5, 2019), researcher at Human Rights Peace Cooperation Office, there were no parties who opposed the construction of the Gwangju Human Rights City. But he added that sometimes people have a misunderstanding about human rights, for example, some Protestantism claims because they hate LGBT (Lesbian, Gay, Bisexual and Transgender) and deny the human rights of those groups. But it's no big deal for constructing human rights city.

Analysis of the process of building a human rights city in Gwangju based on the AgendaBuilding theory, is included in the Outside Initiative model. The May 18 Memorial Foundation, a Non-Profit Organization, became an initiator in collaboration with Gwangju Citizen Solidarity and the Gwangju Metropolitan City Government. In the process these civil society actors and municipalities synergized well up to the stages of the declaration.

Unlike the Gwangju Human Rights City, the initiator and dominant actor in the development of Wonosobo Human Rights City was Regent Kholiq Arif. This mayor who served for two periods (2005-2015) had a central role starting from initiation to declaration. The factors of leadership, knowledge and capacity to mobilize support from various parties became the main capital to successfully realize his idea of building Wonosobo Human Rights Regency. The development process of Wonosobo Human Rights City using the agenda-building theory, is included in the mobilization model.

The Wonosobo Human Rights Regency focuses on public facilities and public spaces that support disability groups, children and the elderly. This began when Regent Kholiq Arif delivered his ideas at May 2013 World Human Rights Cities Forum in Gwangju. A few months later, he wrote in a local newspaper about the importance of implementing human right into local governance by building Wonosobo as a Human Rights City. After that the Regent collaborated with national NGOs such as International NGO Forum on Indonesian Development (INFID) and The Institute for Policy Research and Advocacy (ELSAM) and the National Human Rights Commission (Komnas HAM) to formulate the concept of the Human Rights City that would be implemented in Wonosobo. This collaboration was stated in the memorandum of understanding between the leaders of the four institutions in May 2015.

The process of drafting ordinance began in 2014 as the beginning of the formulation of ideas, continued in 2015, when Wonosobo together with INFID, Komnas HAM, and Elsam signed a MoU which was essentially a collaboration to support the realization of Wonosobo Regency Human Rights-Friendly (Kholiq Arif pers. Comm.). In 2016, Wonosobo formed the legal basis for becoming a human rights city through local government policy (ordinance) No. 5 about Wonosobo Regency Human Rights-Friendly. The idea of localizing human rights and practicing it in Wonosobo, was then followed up by designing the Wonosobo ordinance on Human Rights City. In substance, the draft ordinance mostly adopted the principles contained in the Gwangju Guiding Principles for Human Rights Cities, which were then adapted to the Indonesian constitutional system, was also in line 
with the Constitution of Republic of Indonesia and Law Number 23 Year 2014 concerning Local Governments (INFID 2018, 66).

In the Coordination Meeting of the Ordinance in 2016 which involved various elements of civil society and academia, it was stated that the purpose of this ordinance was declared Wonosobo as a Human Rights Friendly Regency. Because this is the initiation of the local government, the format must be based on ordinance. There were five issues that became the main focus in the discussion regarding the draft ordinance at the time, including: disability, children, public services, health and environment. The five issues arose because they departed from the main problems in Wonosobo and the aspirations of the people involved consultation.

Then in 2018, the Mayor issued Regulation No. 42 of 2018 concerning the Wonosobo Regency Commission on Human Rights. This commission has the task of providing input and consideration to the Regent regarding Regional Policies related to the implementation of Ordinance on Wonosobo Human Rights City, conducting monitoring and evaluation of RADHAM (Draft Regional Action for Human Rights), and conducting education, promotion and mainstreaming human rights issues to the public. The composition of the Commission's membership consists of 2 people from the regional government and 7 people from the community elements (article 4 point 1 ).

The initiator of Wonosobo Human Rights City is the Regent Kholiq as a result of reflection as well as the initiative to form a humanitarian Wonosobo and place human rights as a value. At the beginning of the regent conveyed the idea to build the Wonosobo Human Rights Regency, there were parties from the internal regency government and the local parliament rejecting his idea. The refusal was due to an misconception that building Human Rights City were part of "liberalizing human rights issues" such as the issue of LGBT (Lesbian, Gay, Bisexual and Transgender) rights.

"So my subordinates do not understand. So they oppose a lot. Then the DPR (local parliament) initially also opposed a lot. They understand that Human Rights City is directly related to national or international human rights issues."(Kholiq Arif pers. comm., June 7, 2019)

Regent Kholiq's effort to overcome the rejection of the idea of building the Human Rights City by the internal government and the Wonosobo Regency parliament were carried out with discussion and providing understanding through informal meetings for a period of one year. He also later asked the Chair of the local parliament to attend the WHRCF in 2014 representing Wonosobo.

The Wonosobo Regency Government then allocated funds for the preparation of academic manuscripts for the draft regional regulations, which were also assisted substantially by INFIDand Puskapolham (Center for Political and Legal Studies of Walisongo State Islamic University Semarang). The process of preparing the academic script of ordinance draft was also conducted with a series of workshops and formulation of ideas, which in this case were also assisted by INFID, 
ELSAM, National Human Rights Commission, FNS (Friedrich Naumann Stiftung, an NGO based in Germany), and involved various stakeholders in Wonosobo. The draft was then processed into ordinance in 2016, after Regent Kholiq was replaced because of his term of office in 2015.

During the transition period, the idea of Wonosobo Human Rights City received support from the local parliament (DPRD), especially the chairman of the Afif Nurhidayat who also came to Gwangju WHRCF in 2015. According to Regent Kholiq, the stipulation of ordinance took place quite tough but dynamic. The Special Committee for Draft Regulations in the local parliament stipulates an agreement, but it is necessary to do a final alignment between the Special Committee and the Commission A of the local parliament headed by Suwondo Yudistiro. Finally, the ordinance was approved as Perda (Ordinance) Number 5/2016 dated 7 June 2016 concerning Wonosobo Regency Human Rights-Friendly.

The official Wonosobo declaration as the Human Rights City was first held in July 2015, by Regent Kholiq during the Commemoration of Wonosobo Regency Anniversary. An official of the Wonosobo Regional Development Planning Agency (or abbreviated as Bappeda), as well as being responsible in the Human Rights City Taskforce, Mr. Fahmi (pers. comm., April 4, 2019), said that Wonosobo officially became a Human Rights City in 2015.

\section{Conclusion}

The rise of the human rights cities does not only hold the potential of strengthening social justice in cities worldwide in which these local governments are arguably best placed to deliver it, but also holds considerable promise for the realization of international human rights at a time (Oomen 2016). Gwangju City, which has a strong history of democratization, especially the May 18 Uprising in 1980, had a significant impact on the democratization and enforcement of human rights of the Republic of Korea in the modern era (Cheol 2001; Khan-chae 2003). While Indonesia, which also experienced a phase of democratic transition from a militaristic regime to the more democratic or known as reform era in 1998, haven't made efforts like the Korean people did in resolving past human rights abuse. The experience of each country has an impact on social and political issues at all levels.

There are similarities and differences between the development process of the Human Rights City in Gwangju and Wonosobo. The main difference between the two cities is in background and key issue, as well as the phase of initiation of the human rights city between both regions. The historical background of Gwangju Democratization movement in May 1980 becomes main spirit of the human rights city concept in Gwangju. While in Wonosobo, the triggered issues are vulnerable group such as woman, elderly, child, disability and minority groups and environment. These issues became main concerns of the human rights city policy.

The initiator of the construction of human rights city in Gwangju was civil society and non-governmental organization, specifically Kwangju Citizen Solidarity and May 18 Memorial Foundation. As according to Cobb and Elder (1983), the groups that are the strongest in some sense will determine what issues are going 
to be discussed. In Gwangju case, KCS and the May 18 Foundation which was the strongest group during the initiation stage, brought the issue of the May 18 Democratization Movement to become part of the human rights city policy. While in Wonosobo, the initiator was the Regent, Kholiq Arif who served as leader of the Regency of Government for 15 years. Although his term of office ended in 2015, his influence on the Wonosobo government in endorsing the issuance of ordinance in 2016 was still strong.

Therefore, the agenda-building that took place in the development of Gwangju Human Rights City was more inclined to the Outside Initiative model. As for the case of Wonosobo the Human Rights Regency, the agenda-setting process falls into the type of mobilization. A clear difference in the development process is the time span from initiation to entrance. In Gwangju, the process takes more than ten years. Whereas in Wonosobo it is relatively fast because the initiator is the political leader. However, during the initial stages of internal government discussion, there were rejections from some local officials and legislators due to different perceptions. Those who refuse to think that the status of the Human Rights City will legalize the rights of homosexuals. However, due to the strong leadership of the mayor, he succeeded in convincing the parties and winning the agenda.[]

\section{Acknowledgements}

This article is adapted from my master thesis which submitted for the Master degree in NGO Studies in Department of Non-Governmental Organization Graduate School Chonnam National University, South Korea, 2020.

\section{References}

Central Statistics Agency of the Wonosobo Regency. 2018. "Wonosobo Regency in Figures2018."https://wonosobokab.bps.go.id/publication/2018/08/16/3cafd 8c5e6dd6b244b50de65/kabupaten-wonosobo-dalam-angka-2018.html

Cheol, Kim Yong. 2003. "The Shadow of the Gwangju Uprising in the Democratization of Korean Politics." New Political Science 25, no. 2 (June): 225-240.

Cobb, Roger, Jennie-Keith Ross, and Marc Howard Ross. 1976. "Agenda Building as a Comparative Political Process." The American Political Science Review 20, no. 1 (Maret): 126-138.

Cobb, Roger, and Charles D. Elder. 1983. Participations in American Politics: The Dynamics of Agenda Building." Baltimore and London: The John Hopkins University Press.

Davis, Martha F. 2017. "Design Challenges for Human Rights Cities." Columbia Human Rights Law Review 49, no. 1: 27-66. 
Frate, Benoît. 2016. "Human rights at a local level: The Montréal experience." In Global urban justice: the rise of human rights cities edited by Barbara Oomen, Martha F. Davis, and Michele Grigolo, 64-80. Cambridge: Cambridge University Press.

Gi-goon, Kim. 2012. Human Rights City Project in Gwangju - System Establishment Process and Executed Programs (World Human Rights Cities Forum Report: 2011-2016). Gwangju: GIC \& Gwangju City.

Graham, Emily, Paul Gready, Eric Hoddy, and Rachel Pennington. 2016. "Human rights practice and the city: A case study ofYork (UK)." In Global urban justice: the rise of human rights cities edited by Barbara Oomen, Martha F. Davis, and Michele Grigolo, 179-198. Cambridge: Cambridge University Press.

Gwangju City's Democracy and Human Rights Portal. n.d. http://www.gjhr.go.kr/sub/sub.php?subKey=0101010000.

Gwangju City. 2018. Gwangju: a human rights city. [A hand book]. Gwangju, South Korea: Gwangju City.

Gwangju City. 2019. "Major Policies and Systems of Gwangju as a Human Rights City."https://www.ohchr.org/Documents/Issues/LocalGvt//Local/20190222 Gwangju.docx.

Gwangju Student Independence Movement Memorial Hall. n.d.. "Significance of the Gwangju Student Independence Movement." http://gsim.gen.go.kr/en/?page=020

Hukumonline. 2003. "Penggalian Korban '65 untuk Ungkapkan Fakta [Excavation of '65 Victims to Reveal https://www.hukumonline.com/berita/baca/hol8891/penggalian-korban-65untukungkapkan-fakta/

INFID. 2018. Buku Panduan Kabupaten/Kota HAM Edisi 2018 (Human Rights Cities Handbook 2018). http://www.infid.org/buku-panduan-kabupatenkotaham-2018/

Jong-cheol, Ahn. 2002. "The Significance of Settling the Past of the December 12 Coup and the May 18 Gwangju Uprising." ekoreajournal 42, no. 3 (Autumn): 112-138.

Kahn-chae, Na. 2001. "A New Perspective on the Gwangju People's Resistance Struggle: 1980-1997." New Political Science 23, no. 4: 477-491.

Kompas. 2016. "Penyelidikan Komnas HAM Pernah Ungkap Adanya Pembunuhan Massal 1965-1966 [Komnas HAM Investigation Ever Revealed the existence of Mass Murder 1965-1966]." Kompas.com, April 27. 
https://nasional.kompas.com/read/2016/04/27/08250761/Penyelidikan.Ko mnas.HAM.Pernah.Ungkap.Adanya.Pembunuhan.Massal.1965-1966

Lee, Kwang-Suk. 2007. "Questioning a neoliberal urban regeneration policy: the rhetoric of Cities of Culture and the City of Gwangju, Korea." The international journal of cultural policy 13, no. 4: 335-347.

Marks et. al. 2008. "Human Rights Cities: Civic Engagement for Societal, PDHRE." http://www.pdhre.org/HumanRightsCitiesBook.pdf.

Nurkhoiron, Muhammad. 2017. "Mengembangkan Kota HAM di Indonesia: Peluang dan Tantangannya." Jurnal Pemikiran Sosiologi 4, no. 1: 120-147.

Oomen, Barbara. 2016. "Introduction: The promise and challenges of human rights cities." In Global urban justice: the rise of human rights cities edited by Barbara Oomen, Martha F. Davis, and Michele Grigolo, 1-20. Cambridge: Cambridge University Press.

Oomen, Barbara, and Esther Van Den Berg. 2014. "Human Rights Cities: Urban Actors as Pragmatic Idealistic Human Rights Users." Human Rights \& International Legal Discourse 8, no. 2: 160-185.

OHCHR. 2014. "Achievements and Challenges of the Human Rights City GwangjuOverview and Tasks of the Implementation of the Human Rights City Gwangju."https://www.ohchr.org/Documents/HRBodies/HRCouncil/Advisor yCom/LocalGvt/Gwangju\%20Metropolitan\%20City,\%20Republic\%20of\%20K orea.pdf.

OHCHR. n.d. "Local Government and Human Rights." https://www.ohchr.org/EN/Issues/LocalGovernment/Pages/Index.aspx

Prayudi. 2014. "Decentralization in the Indonesian Government System: State Politics in Center - Region Relations". Jurnal DPR RI [Journal of the Indonesian $\begin{array}{llll}\text { Parliament] } 19, \quad \text { no. } & 401 .\end{array}$ https://jurnal.dpr.go.id/index.php/kajian/article/view/561/456.

Setyawan, Ahmad Dwi. 2012. "Conflicts of interest among stakeholders involving ecology, economy and socioculture of the Dieng Plateau, Indonesia." GEOGRAFIA Online, Malaysia Journal of Society and Space 8 no. 4: 88-104. http://journalarticle.ukm.my/5506/1/9a.geografia-jul_2012-Setyawan-unsmelayued\%2520kat.pdf

Suprapto, Edi, and Agus Budi Purwanto. 2013. Hutan Jawa: Kontestasi dan Kolaborasi [Java Forest: Contestation and Collaboration]. Yogyakarta: Biro Penerbitan Arupa.

Tempo. 2013. “Cara Bupati Wonosobo Kholiq Redam Konflik [The Wonosobo Regent Kholiq's Way of Reducing Conflict]." Tempo.co. 
https://nasional.tempo.co/read/506151/cara-bupati-wonosobo-kholiqredam-konflikagama/full\&view=ok

The Association of North East Asia Regional Governments. (n.d.). "Gwangju Metropolitan City." http://www.neargov.org/en/page.jsp?mnu_uid=3610

UCLG. 2011. "Gwangju Declaration on Human Right City." www.uclgcisdp.org/sites/default/files/Gwangju_Declaration_on_HR_City_final _edited_version_110524.pdf

UN Human Rights Council. 2014. "Progress report of the Advisory Committee on the role of local government in the promotion and protection of human rights, including human rights mainstreaming in local administration and public services."https://www.shareweb.ch/site/DDLGN/Documents/Role\%20of\%2 0Local\%20Governance\%20in\%20HR.pdf.

UN Human Rights Council. 2019. "Local government and human rights: Report of the United Nations High Commissioner for Human Rights (A/HRC/42/22)."

UN Human Rights Council. 2015. "Role of local government in the promotion and protection of human rights: Final report of the Human Rights Council Advisory Committee (A/HRC/30/49)."

Van Den Berg, Esther. 2016. "Making human rights the talk of the town: Civil society and human rights cities, a case study of the Netherlands." In Global urban justice: the rise of human rights cities edited by Barbara Oomen, Martha F. Davis, and Michele Grigolo, 44-63. Cambridge: Cambridge University Press.

Ward, JoAnn Kamuf. 2016. "From principles to practice: The role of US mayors in advancing human rights." In Global urban justice: the rise of human rights cities edited by Barbara Oomen, Martha F. Davis, and Michele Grigolo, 81-100. Cambridge: Cambridge University Press.

Wonosobo Regency Government. 2014. "Potential Investment of Wonosobo Regency. Potensi

Daerah." https://wonosobokab.go.id/website/index.php/2014-02-01-04-4052/potensi-daerah/potensi-investasi-kabupaten-wonosobo.

World Human Righs Cities Forum. 2011. "2011 World Human Rights Cities Forum.” http://whrcf.org/file_Download/world_world02_eng.pdf.

\section{Author Biography}

Zico Mulia is a program officer at Tifa Foundation. He completed his Master's degree in NGO Studies in Department of Non-Governmental Organization Graduate School Chonnam National University, South Korea. His research interests encompass human rights and transitional justice.

Email: zico.mulia@gmail.com 